\title{
Low-skill jobs or jobs for low- skilled workers? An analysis of the institutional determinants of the employment rates of low-educated workers in 19 OECD countries, | 997-20|0
}

Journal of European Social Policy 2015, Vol. 25(2) 225-24I (c) The Author(s) 2015 Reprints and permissions: sagepub.co.uk/journalsPermissions.nav DOI: $10.1177 / 0958928715573485$ esp.sagepub.com

(SAGE

\author{
Aurélien Abrassart \\ University of Konstanz, Germany
}

\begin{abstract}
We often hear that the high unemployment rates of low-educated workers in Europe are due to the rigidities of the institutions increasing the labour costs that burden employers. In this article, we challenge this traditional view and offer alternative explanations to the cross-national variation in the employment rate of low-educated workers. Using macro-data and an error correction model, we analyse the determinants of the creation of jobs for low-educated workers in 19 countries between 1997 and 2010. Our findings tend to invalidate the neoliberal view, while also pointing to the positive impact of investing in public employment services and the predominant role of economic growth, which can be weakened by union density and employment protection in the case of male workers. Last but not least, creating low skill jobs has no or little impact on the employment outcomes of low-educated workers, thus indicating job displacement issues.
\end{abstract}

\section{Keywords}

Active labour market policies, economic growth, employment, job displacement, labour market flexibility, low-educated workers

\section{Introduction}

With the rise of tertiarization and the knowledge-based economy, the employment prospects of workers have considerably evolved compared to the golden years of capitalism, which were characterized by high industrial employment and low unemployment among lowskilled workers. The recent structural changes of our modern post-industrial economies have had particularly detrimental consequences for some specific groups of workers, among which are those with only low educational qualifications (Bonoli, 2007). Furthermore, it appears that most of the variation across countries in

\footnotetext{
Corresponding author:

Aurélien Abrassart, University of Konstanz, 78457 Konstanz, Germany.

Email: aurelien.abrassart@uni-konstanz.de
} 
their employment performance occur at the level of workers with below upper secondary education (Bonoli, 2012; Organisation for Economic Co-operation and Development (OECD), 2012). National institutional settings therefore seem to be determinant in the extent to which workers with low educational qualifications suffer from these recent structural changes. Identifying not only the ones that matter but also the ones that contribute to an improvement of their employment situation may also give policy-makers the opportunity to plan a better future for such disadvantaged groups of workers.

The debate on this topic has largely been dominated by the tension between the conventional wisdom regarding this problem, which maintains that the rigidity of labour markets is the main source of the employment disadvantage of low-skilled workers (e.g. OECD, 1994; Siebert, 1997), and the lack of empirical support for this traditional view (Avdagic and Salardi, 2013; Baccaro and Rei, 2007; Bradley and Stephens, 2007; DiPrete, 2005; EspingAndersen, 2000; Howell et al., 2007). However, we lack the theoretical basis to explain the recent labour market developments and its consequences for the low-educated group. After reviewing the mixed evidence on the empirical support of the conventional wisdom, Howell et al. (2007) note that our need for a predominant explanation may be misguided as a result of the numerous institutional factors underlying the complexity of modern labour markets. In their view, a dominant theory is unable to explain the different 'success stories' in terms of employment performance. And while the institutionalist perspective provides a credible alternative to the explanation of the cross-national variation in overall employment performance among OECD countries (Bradley and Stephens, 2007), there is to our knowledge no evidence yet that this may also be the case for loweducated workers.

Recent developments on the explanation of the higher labour market disadvantage of low-educated workers emphasize the importance of the socioeconomic and skill composition of this group (Abrassart, 2013; Gesthuizen et al., 2011). However, job displacement mechanisms appear to be even stronger determinants of their employment disadvantage (Abrassart, 2013), thus pointing at the importance of skill matching, which depends on the occupational structure and activation strategies of developed economies, for the employment prospects of low-educated workers. Additionally, the particularly detrimental consequences of economic downturns and their interaction with institutional settings in the creation or destruction of jobs for low-educated workers are often ignored. Whether it is mainly labour market regulation, social policies, economic fluctuations or particular combinations of these factors that explain the important cross-national variation in the employment disadvantage of low-educated workers hence remains an open question. In this article, we try to answer it by analysing time-series cross-section data covering 19 OECD countries over the 1997-2010 period using an autoregressive distributed lag (ADL) model in error correction (EC) form.

\section{Theoretical framework}

\section{The costs of labour as the main driver of job creation?}

The cost of labour is often identified as the main culprit in the unemployment problem. Although it is often designated as labour market rigidity (e.g. Siebert, 1997), what is implied is the cost of labour market regulation affecting employers, which is supposed to be 'the only valid index of the effect of institutions on the labor market' (Heckman, 2007). Accordingly, here, the cost of labour must be understood in the broad sense, that is, as all the costs involved in the hiring and firing decision-making procedures of employers and affected by institutions. They include wages, the (dismissal) costs resulting from the strictness of employment protection legislation (EPL), non-wage costs through social contributions and consumption taxes and, more indirectly, the generosity of unemployment benefits affecting the setting of attractive wages as a result of an increase in the reservation wage.

These costs are expected to impede on the creation of low-skill jobs for several reasons. First, the competition from Third World countries is increasing the downward pressure on labour costs in developed economies to avoid outsourcing. Second, because countries in the European Monetary Union cannot devaluate their currency any more to increase 
competitiveness, they increasingly have to rely on internal devaluations. Finally, and what is more important, as a result of tertiarization and skillbiased technological change (SBTC), the relative productivity of low-skilled workers has considerably declined. With SBTC substituting for routine tasks and complementing non-routine tasks at the workplace (Autor et al., 2003), skilled workers are increasingly needed in the manufacturing sector, making low-educated people unable to compete and confined to jobs in the low-end service sector, where technology cannot foster productivity gains. In addition, low-end service sector jobs are also characterized by a high price elasticity that prevents the linkage of wages in this sector to other more productive sectors (Esping-Andersen, 1999; Iversen and Wren, 1998). As a result, in countries without the necessary wage flexibility, employment growth will therefore be lower, resulting in higher unemployment, especially among low-educated individuals.

Two main wage-setting institutions, in particular, are expected to determine the extent of the rigidity of wages and its consequences for employment: wage setting coordination and trade union density. Although the neoliberal vision of labour markets maintains that both institutions are harmful for employment, the corporatism literature rather insists on their potential positive impact on employment performance. While the former encourages more flexibility through lower coordination (or more bargaining decentralization) to improve labour market performance, the latter suggests, on the contrary, that a more encompassing or more coordinated wage bargaining will, essentially through wage restraint and the internalization of unemployment-fighting measures, actually foster employment. Both schools, however, tend to agree with the fact that, controlling for wage setting coordination, union density will have a somewhat negative impact on employment as a result of the greater wage increases it induces (Bradley and Stephens, 2007; Kenworthy, 2003).

Second, social contributions and consumption taxes are also expected to hamper the creation of lowskill jobs because of the economic burden they impose on employers in high price-elasticity sectors. Indeed, with wages already at low levels in such jobs, almost nearing the reservation wage, employers have no other choice than to bear these costs entirely, while being constrained by the need to offer goods and services at low prices (Scharpf, 2000: 80). As a result of the higher prices, consumption taxes will affect the demand of the goods and services on which they are levied and therefore employer revenues (Kenworthy, 2008: 185). Furthermore, social security contributions and taxes on payroll paid by employers will 'increase nonwage labor costs', while those paid by employees 'may lead to employee (or union) demands for higher wages to compensate for the tax payments, thereby increasing labor costs for employers' (Kenworthy, 2008: 185).

In a more indirect way, EPL and unemployment benefits are also expected to influence the employment opportunities of low-educated workers. In the first case, the strictness of the legislation determining the degree of employment protection workers can enjoy will affect the hiring and firing decisions of employers as a result of the important turnover costs it may impose. Obviously, the implications of the strictness of this legislation will differ depending on whether we consider regular or temporary employment. Increasing the flexibility of the legislation of fixed-term contracts is, for instance, expected to foster the employment of low-skilled workers by allowing for a better adjustment to economic fluctuations or to allow for the screening of employees in a strict legislation environment in the case of regular employment (Kahn, 2005; Maurin and Postel-Vinay, 2005). As Cahuc and Postel-Vinay (2002) summarize, it is 'generally concluded that the introduction of fixed-duration contracts is equivalent to a reduction in firing costs'.

Rather than an increase in the flexibility of the legislation for regular contracts, what can be observed in the past decades in many countries has been a trend towards a deregulation in the case of fixed-term contracts (Eichhorst and Marx, 2012; Lodovici, 2000; Palier and Thelen, 2010), thus giving employers and temporary work agencies greater leeway with regard to the duration, working conditions or maximum successive number of such contracts. Some authors have identified this deregulation of the labour market at the margin as the European way to cope with the structural changes of our modern economies, instead of directly allowing for more wage flexibility as in 
Anglo-Saxon countries (e.g. DiPrete, 2005). However, a more flexible temporary employment legislation may not necessarily result in a higher employment performance, especially when the legislation for regular contracts is strict, and as a result the firing costs are high. The danger here resides in employers overusing these precarious forms of employment in a strict regulatory context in the case of regular employment, without necessarily converting fixed-term contracts into permanent ones. Ultimately, the destruction of jobs through deregulation at the margin may become greater than the creation induced at the beginning through higher flexibility (Blanchard and Landier, 2002; Cahuc and Postel-Vinay, 2002).

Finally, as is often argued in the literature, unemployment benefits are likely to reduce the supply of low-skilled workers because more generous benefits cause an increase in the reservation wage of such workers (e.g. Esping-Andersen, 2000; Howell et al., 2007; Oesch, 2010). Given the mixed evidence, there are, however, reasons to doubt this expected detrimental influence of unemployment benefits, especially when looking at the macro-level (Howell et al., 2007). On the contrary, more generous benefits and of longer duration may increase the matching of skills in the labour market as unemployed workers will feel less compelled to accept the first job they find and will have more time and resources to find a job that fits their expectations. As a result, job turnover should be lower in the long run as the satisfaction of workers increases (Estevez-Abe et al., 2001; Gangl, 2004). Recent developments in active labour market policies (ALMPs) may, furthermore, compensate the supposedly negative effect of unemployment benefits generosity.

\section{Improving the matching of skills in the labour market}

The previous approach on the costs neglects the importance of the matching process, as well as the impact of labour market and social policies on the incentives, or disincentives, to (re-)enter the labour market and the employability of low-educated workers often depending on information problems. Thus, while this approach may be adequate to describe patterns of job creation, it is unable to account for skill mismatches in the labour market and the employment opportunities of a particular group of workers.

The shift of modern welfare states from their decommodifying function towards a more activationoriented strategy can be understood as the policy response to these matching issues (Bonoli, 2010; Clasen and Clegg, 2003). ALMPs are indeed believed to be able to help unemployed workers in general, and more particularly low-educated workers, (re-) integrate into the labour market more easily. These policies include, for instance, training measures, as well as job subsidization and direct job creation (mainly in the public sector). Whether these measures are actually effective, however, remains to be observed. At the micro-level, it appears that the outcomes of job subsidization or direct job creation may be disappointing (e.g. Bonoli, 2012; Marx, 2001). Both measures mainly act on the cost of labour borne by employers and mostly affect the incentives to hire individuals normally deemed as 'unsuitable'. While job subsidizing may, through a reduction in labour costs, incite employers to hire unemployed workers that they would not have otherwise hired, it may also heighten the stigma carried by the targeted workers, who will, 'more than ever before, be labelled "problem cases"" (Marx, 2001: 81). When subsidization is not targeted, however, a different issue surfaces: those who seem to benefit from it are those who would have been hired regardless of the measure, leaving the most disadvantaged workers unaffected by the policy because of this screening effect (Marx, 2001). The evaluation literature on the impact of direct job creation shows that this measure has a negative or no significant effect on the future employment outcomes of workers, who seem to suffer from a 'strong lock-in effect' resulting from a reduction in their search efforts (Bonoli, 2012: 16). A strong Matthew effect ${ }^{1}$ may also be present in the case of training measures, which further increases the disadvantage of low-educated individuals, because the success of these measures may depend on the possession of basic general skills such as cognitive and noncognitive skills (e.g. Abrassart, 2013; Bonoli, 2012). On the other hand, evaluation of public employment service programmes, which help people in their job searches and with motivation, points at the relevance of such measures for low-skilled workers (e.g. Oesch, 
2010; Weber and Mahringer, 2008). In this article, we aim to give evidence on the effect of these policies at the macro-level.

Probably the most important weakness of the previous approach solely focusing on the cost of labour and the creation of low skill jobs is the fact that it does not account for job displacement issues. The assumption that job vacancies in low-skill sectors will be filled by low-skilled people is indeed becoming increasingly challenged, as workers with tertiary or upper secondary education crowd low-educated workers out of the labour market, while occupying jobs that clearly do not match their level of skills (Gesthuizen et al., 2011; Goos and Manning, 2007). Therefore, creating jobs in low-skill sectors such as in low-end services may not necessarily mean increased job opportunities for those at the bottom of the skill distribution. The main explanation lies in the increasing polarization of the skill demand that affects some countries (Goos and Manning, 2007; Oesch and Menés, 2011). More precisely, it is possible to witness a hollowing out of jobs in the middle of the wage distribution, while low- and high-end service jobs expand rapidly. If the supply of workers does not adapt to this evolution of the occupational structure, important mismatches between the supply and the demand are to be expected at different skill levels. Since recent trends point at the rapid educational expansion in post-industrial societies that has exceeded the demand for high-skill jobs, while workers who have been made redundant as a result of the hollowing out of occupations at the middle of the distribution fall back on low-skill jobs, this results in an increasing competition for low-end service sector jobs. Despite the low-skill requirements of these jobs, we can expect employers to prefer medium- and high-educated workers to their low-skilled counterparts, as they are more likely to possess the cultural and social skills valued in these occupations (EspingAndersen, 1999). However, this contrasts with the argument that low-educated workers constitute a more docile and cheap alternative for employers, and that they should accordingly prefer them to their better-educated counterparts. Moreover, it appears that this polarization is only made possible by the flexibility of the wage distribution, as countries with a more rigid wage-setting process do not necessarily suffer from this development of the occupational structure (Oesch and Menés, 2011).

\section{The importance of the economic context}

SBTC and the development of low-end service sector jobs have significantly contributed to the decline of the productivity of low-skilled workers as compared to the rest of the labour force. Thus, this does not come as a surprise that economic downturns mostly affect low-skilled workers, who generally are the first to be dismissed as turnover costs are lower in their case (Gautier et al., 2002; Oesch, 2010). Furthermore, with the flexibilization of employment relationships at the margin in Europe, the employment opportunities of low-educated workers have become more dependent on economic fluctuations as dismissal procedures have become less regulated. More particularly, as previously mentioned, employers use temporary employment as a means to adjust more easily to economic fluctuations. The strictness of the legislation in the case of regular employment may, however, protect employees against dismissals during economic downturns while also limiting the hiring of new employees during growth periods, as employers will be aware of the costly barriers to dismissals, especially in the case of low-educated workers.

Finally, the power of unions and the level of coordination of wage bargaining may also moderate the impact of economic fluctuations on the employment opportunities of low-educated workers. More precisely, a more decentralized and flexible wage-setting process may tame the effect of economic downturns on the employment of low-skilled workers, as wages will adapt more rapidly to a decline in demand. On the other hand, highly coordinated wage-setting processes may also further enhance the positive employment effect of economic growth to benefit a higher share of workers instead of only those in particular industries or sectors (Garrett and Way, 1999; Hicks and Kenworthy, 1998). Which effect prevails needs to be empirically determined. Strong unions, however, while controlling for the degree of coordination of the wage bargaining, wish, above all, to protect the interests of their constituencies. During economic downturns, this could lead to fewer dismissals of workers. During economic 
recovery, however, this might result in demands for higher wages that will reduce the positive employment impact of growth.

\section{Differentiated impact of institutions by gender}

Finally, women, because of their higher likelihood to interrupt their career and to work in the low-end service sector when they possess only low levels of skills, might be affected in a different manner by the previous institutions. In particular, more encompassing wage-setting institutions are likely to favour insider male workers in the manufacturing sector while further excluding outsider women working in low-end service jobs (Eichhorst and Marx, 2012; Emmenegger et al., 2012). The trade-off between employment growth and wage equality may thus be particularly acute in the case of women.

Furthermore, their willingness to work also depends on the interaction between household composition, income and family policies. With the development of homogamy, namely, the increasing matching of partners within a household according to their education and socioeconomic background, and the growing instability of the family structure, the need to work for low-educated women in order to secure a sufficient household income has become more salient than ever. There are, however, good reasons to believe that political and cultural factors are also important determinants of the supply of labour by low-educated female workers. In particular, family policies play a central role in the reconciliation of work and family life. Cultural aspects may, however, still be at play in the determination of the supply of labour by women. Accordingly, we expect economic growth to have a lower impact in the short run on the employment rate of women. ${ }^{2}$

\section{Data and methodology}

\section{Data and variables}

Our dependent variable in this study is the employment rate of workers aged 25-54 years with below upper secondary education, by gender. In our analyses, 19 OECD countries were included: Australia,
Austria, Belgium, Canada, Denmark, Finland, France, Germany, Ireland, Italy, The Netherlands, New Zealand, Norway, Portugal, Spain, Sweden, Switzerland, United Kingdom and the United States. Information on the employment rates of low-educated workers was available from 1997 until 2009 in the case of men and from 1997 until 2010 for women depending on the model. The data employed have mainly been compiled from the OECD Education at a Glance reports as well as the OECD online databases. Some variables required reliance on other databases, which are mentioned in the following paragraphs.

In order to measure the impact of the cost of labour on our dependent variable, we first measure the wage costs of labour. In order to do so, both union density and the coordination of wage bargaining are included as independent variables (Visser, 2011). Wage inequality as measured by the ratio of the 5 th to the 1 st decile of earnings was also used as an alternative measure to the previous variables. Due to missing data and the non-significance of the variable, we decided not to retain this indicator in our analyses (available upon request). Because we expect the effect of union density to be nonlinear, and more precisely concave, we introduce the square of the measure of union density as well. This is justified by the fact that an increase in union membership in already high unionized countries will probably not result in an equivalent increase in employment for low-skilled workers. On the other hand, in low unionized countries, an increase in union density is likely to have a greater influence on the employment prospects of low-educated workers. Then, consumption taxes, as well as social contributions and payroll tax revenues as a percentage of gross domestic product (GDP), are integrated to account for nonwage costs. Finally, we use the OECD EPL index for regular and temporary contracts and net replacement rates for an average production worker (Van Vliet and Caminada, 2012). The mean of these rates for a single-earner couple with two children and for a single person was computed and used. Because the information was only available from 2001, we were unfortunately unable to distinguish between the lengths of benefits.

On the side of the determinants of the matching of skills, spending on public employment services, 
training, employment incentives, as well as direct job creation ALMPs as a percentage of GDP, divided by unemployment rates, were included in the models. To account for job displacement issues, we use the share of employment in low-skill occupations, here measured as employment of male and female workers in categories 5 and 9 of the International Standard Classification of Occupations (ISCO), corresponding, respectively, to service and sale lowskilled workers and to elementary occupations, as a percentage of, respectively, male and female employment. ${ }^{3}$ This variable is integrated while also controlling for the proportion of male and female workers aged 25-54 years with below upper secondary education. No significant effect or a negative significant effect of the share of low-skill employment may expose the lack of influence of the creation of low-skill jobs on the employment opportunities of low-educated workers, all other things being equal. A greater share of such jobs in the economy may also be a sign of the polarization of the labour market and of the disappearance of middle-skill jobs. We argue that the risk of endogeneity of this variable due to simultaneity with the dependent variable is rather low as the correlation between these variables computed for both men and women was also low. Furthermore, this variable is an indicator of the structural aspects of the occupational structure in relative terms, hence also depending on the share of employment in other sectors. Accordingly, it should not necessarily vary with the employment rate of low-educated workers, precisely because of job displacement issues. Finally, annual GDP growth is used to measure economic fluctuations.

In the case of women, we control for public and mandatory private cash benefits for maternity and parental leave, benefits in kind for daycare and home-help services, and spending in kind on old age and incapacity, all three as percentage of GDP. These are rather crude measures of family and care policies, but unfortunately only spending measures were available for the period considered. Finally, public sector employment as a percentage of the population aged 15-64 years is used here to verify that the effect of tax revenues on the employment rate is not due to a higher share of jobs in the public sector. Because none of these variables were significant, we do not include them in the final models.

\section{Methodology}

Time-series cross-section analyses have been subject to many debates with regard to which method and model specification is better adapted to increase the robustness of the results (e.g. Beck and Katz, 2001; Plümper et al., 2005). There is unfortunately no real consensus in the literature, but constantly improving guidelines prevents researchers from obtaining biased results. Here, we mainly follow the steps described by Beck and Katz (2011), while implementing a variety of robustness tests to confirm the validity of our findings. We first start with the specification of our model.

Because the dependent variable is slowly varying over time and thus appears to be non-stationary, ${ }^{4}$ making its lag the best predictor possible as well as causing spurious regression (the main reason why other more traditional models have been discarded), we use an ADL model in EC form, which can be written in the following form

$$
\Delta \mathrm{y}_{\mathrm{it}}=\alpha+\beta_{0} \Delta \mathrm{x}_{\mathrm{ijt}}+\beta_{1} \mathrm{y}_{\mathrm{it}-1}+\beta_{2} \mathrm{x}_{\mathrm{ijt}-1}+\varepsilon_{\mathrm{it}}
$$

The subscripts $i, t$ and $j$ refer, respectively, to the particular country, year and independent variable. This model is equivalent to a first difference model, where $\Delta$ is the first difference operator, while also including the first lag of the dependent (y) and independent variables $(\mathrm{x})$ to account for long-term adjustments.

The main advantage of the ADL model in EC form is, therefore, that it accounts for both short- and long-term dynamics while correcting for a potential non-stationarity or a slow variation in the dependent variable. It is important to be precise, for a clear interpretation of our findings that follow, that firstdifferenced explanatory variables only measure a transitory effect, while their lag allows us to determine the extent of their permanent impact on the central variable to explain here the change in the employment rate. In other words, coefficients of 
first-differenced predictors will indicate the size of their immediate effect on employment rates without having any long-run influence. If the predictor were to return to its previous value, the dependent variable would also return to its value before the variation of the former. The coefficient of the lagged variable will inform us about the variation in the equilibrium relationship between this predictor and the dependent variable, which will vary as a result of a one-unit increase in the former (Beck and Katz, 2011; Iversen and Cusack, 2000; Iversen and Wren, 1998). This overall long-term effect will be spread over several periods, here years, until the employment rate no longer varies as a result of the past variation in the independent variable. We present the most consistent models through the progressive elimination of non-significant predictors, starting from the full model. ${ }^{5}$ In all models, we use panel-corrected standard errors.

\section{Findings}

We first start with our findings concerning male loweducated workers. As we can observe in Model 3 (Table 1), when looking at the determinants measuring the cost of labour borne by employers in the broad sense, four variables have a significant impact, namely, union density, which has, as expected, a negative and concave influence on the employment rate; temporary employment protection; consumption taxes and net replacement rates. In the last three cases, however, the impact goes in the opposite direction to what could have been expected based on the literature supporting the conventional wisdom.

More particularly, net replacement rates have a positive long-term effect on the employment rates, which confirms the institutionalist perspective on the importance of the generosity of benefits for the matching of skills in the labour market. Moreover, it appears that the strictness of the legislation regulating the leeway of temporary work agencies has a short- and long-term positive effect on the employment rate of low-skilled male workers. More precisely, a 1 standard deviation change in the index of protection would disrupt the equilibrium state between these two variables by a 4.17 percentage points increase in the employment rate. ${ }^{6}$ Our results thus support the claim that a looser legislation may not necessarily result in a higher employment performance, as employers will tend to overuse temporary employment and will not necessarily convert these precarious jobs into more stable forms of employment, resulting in a loss of jobs for the whole economy and particularly for low-skilled workers (Blanchard and Landier, 2002; Cahuc and PostelVinay, 2002). Furthermore, we also show that this effect is independent of the strictness of the legislation for regular employment, as the interaction effect between both factors is not significant (Model 2). Thus, a stricter legislation in the case of temporary employment protection probably acts as an incentive to create more stable jobs that increase the overall rate of employment of low-educated workers.

Another explanatory variable that has a counterintuitive effect is the one measuring consumption taxes revenues as a percentage of GDP. Indeed, a 1 standard deviation increase in consumption tax revenues yields an immediate positive effect of 4.21 percentage points of the low-skilled male employment rate. However, this probably reflects a consumption effect on the employment level, given that it is the revenues of such taxes and not their rates that are measured here. It is thus likely that higher levels of consumption in the sectors of the economy affected by these taxes may engender employment for loweducated people, ${ }^{7}$ independently of economic growth. The potential influence of public employment is, moreover, excluded as controlling for public sector employment does not alter this effect for men (model not shown, available upon request).

Among the ALMPs variables, three have a significant impact and have therefore been retained in Model 3. In the case of spending on public employment services, the positive effect on the employment of low-skilled workers is confirmed, both in the short and long run. Thus, a 1 standard deviation increase in spending on these measures will yield an immediate positive impact of 1.42 percentage points and will also increase the long-term relationship between the former and the dependent variable by 5.58 percentage points. Training efforts also seem to increase the employment opportunities of men, albeit only moderately and in the short run. On the other hand, in the case of direct job creation, the 
Table I. The determinants of the employment rates of low-educated male workers.

\begin{tabular}{|c|c|c|c|c|}
\hline & & \multicolumn{3}{|l|}{ Men } \\
\hline & & Model I & Model 2 & Model 3 \\
\hline Low-educated male employment rate & Lag & $-0.13 * *$ & $-0.13 * * *$ & $-0.12^{* * *}$ \\
\hline \multirow[t]{2}{*}{ Union density } & First difference & $-7.69 * *$ & 5.93 & 4.67 \\
\hline & Lag & $-0.37^{*}$ & 0.33 & -0.07 \\
\hline \multirow[t]{2}{*}{ Union density squared } & First difference & & $-11.66 *$ & $-10.83^{*}$ \\
\hline & Lag & & -0.62 & -0.26 \\
\hline \multirow[t]{2}{*}{ Coordination of wage bargaining } & First difference & $0.58^{*}$ & 0.31 & \\
\hline & Lag & 0 & -0.53 & \\
\hline \multirow[t]{2}{*}{ Permanent EPL } & First difference & 0.51 & 1.18 & 0.73 \\
\hline & Lag & -0.40 & 0.70 & 0.11 \\
\hline \multirow[t]{2}{*}{ Temporary EPL } & First difference & $2.12 * *$ & 3.17 & $2.46 * *$ \\
\hline & Lag & $0.43 * *$ & 1.01 & $0.50 * *$ \\
\hline \multirow{2}{*}{ Consumption tax revenues } & First difference & $3.92 * * *$ & $3.64 * * *$ & $4.21^{* * * *}$ \\
\hline & Lag & 0.3 & 0.05 & 0.10 \\
\hline \multirow{2}{*}{ Social contributions } & First difference & 1.65 & 1.89 & \\
\hline & Lag & -0.09 & -0.03 & \\
\hline \multirow[t]{2}{*}{ Net replacement rate } & First difference & -1.24 & -1.30 & -1.24 \\
\hline & Lag & $0.39 *$ & $0.48 * *$ & $0.3 I^{*}$ \\
\hline \multirow[t]{2}{*}{ Public employment services } & First difference & $1.29 * * *$ & $1.52^{* * *}$ & $1.42 * * *$ \\
\hline & Lag & $0.57^{* *}$ & $0.63^{* * *}$ & $0.67^{* * * *}$ \\
\hline \multirow[t]{2}{*}{ Training } & First difference & 0.59 & $0.77^{*}$ & $0.73^{*}$ \\
\hline & Lag & -0.06 & 0.05 & 0.01 \\
\hline \multirow[t]{2}{*}{ Employment incentives } & First difference & -0.22 & -0.17 & \\
\hline & Lag & 0.01 & 0 & \\
\hline \multirow[t]{2}{*}{ Direct job creation } & First difference & -0.63 & $-0.77^{*}$ & -0.54 \\
\hline & Lag & $-0.36^{*}$ & $-\left.0.4\right|^{* *}$ & $-0.42^{* * *}$ \\
\hline \multirow{2}{*}{$\begin{array}{l}\text { Share of men in ISCO } 5 \text { and } 9 \text { jobs, } \\
\text { as a percentage of total employment }\end{array}$} & First difference & 0.19 & 0.21 & 0.16 \\
\hline & Lag & $-0.35^{*}$ & $-0.32^{*}$ & $-0.3 I^{*}$ \\
\hline \multirow{2}{*}{$\begin{array}{l}\text { Proportion of low-educated male } \\
\text { workers }\end{array}$} & First difference & 1.49 & 1.69 & 1.66 \\
\hline & Lag & $0.43^{*}$ & $0.57^{*}$ & $0.4 I^{*}$ \\
\hline \multirow[t]{2}{*}{ Growth } & First difference & $0.74 * * *$ & $0.97 *$ & $1.24 * *$ \\
\hline & Lag & $\left.1.4\right|^{* * * *}$ & $1.90 * *$ & $2.75^{* * * *}$ \\
\hline Interaction permanent & First difference & & -1.19 & \\
\hline EPL $\times$ temporary EPL & Lag & & -1.21 & \\
\hline Interaction growth $\times$ wage & First difference & & 0.10 & \\
\hline coordination & Lag & & 0.89 & \\
\hline \multirow[t]{2}{*}{ Interaction growth $\times$ union density } & First difference & & $-0.74 * * *$ & $-0.75 * * *$ \\
\hline & Lag & & -0.42 & -0.24 \\
\hline \multirow[t]{2}{*}{ Interaction growth $\times$ permanent EPL } & First difference & & -0.04 & 0.10 \\
\hline & Lag & & $-1.48^{* *}$ & $-1.18^{* * *}$ \\
\hline \multirow[t]{2}{*}{ Interaction growth $\times$ temporary EPL } & First difference & & 0.49 & \\
\hline & Lag & & 0.65 & \\
\hline \multicolumn{2}{|l|}{ Constant } & $9.57 * *$ & $|0.7| * * *$ & $9.28 * * *$ \\
\hline \multicolumn{2}{|l|}{$\mathrm{N}$} & 19 & 19 & 19 \\
\hline \multicolumn{2}{|l|}{ Average $\mathrm{T}$} & 10.63 & 10.63 & 10.63 \\
\hline \multicolumn{2}{|l|}{ n } & 202 & 202 & 202 \\
\hline $\mathrm{R}^{2}$ & & 0.63 & 0.67 & 0.65 \\
\hline
\end{tabular}

EPL: employment protection legislation; ISCO: International Standard Classification of Occupations. Standardized coefficients.

$* p<0.05 ; * * p<0.01 ; * * * p<0.001$. 
higher the spending, the lower the employment opportunities in permanent terms. Thus, instead of helping low-skilled workers reintegrate into the labour market, it may strengthen the stigmatization effect of possessing only low educational qualifications and create a lock-in effect.

Then, including the share of male employment in low-skill jobs (and the proportion of male workers with below upper secondary education), we observe that this newly introduced variable has a significant negative long-run effect of 2.58 , likely indicating job displacement issues. Moreover, the proportion of male workers with below upper secondary education positively affects the employment opportunities of these workers in a long-run perspective. This positive effect seems to confirm the theory suggesting that the smaller this group of disadvantaged workers, the higher the stigmatization effect (e.g. Gesthuizen et al., 2011) and the higher the risks of job displacement, as this may also be a sign of strong educational expansion.

Finally, growth seems to be of great importance for the male low-skilled employment performance, as it positively affects this performance, both in the short and long run. More particularly, the permanent effect of a 1 standard deviation increase in growth rate has a positive impact of 10.85 percentage points on the equilibrium relationship between the employment rate of male low-skilled workers and this predictor (Model 1). Thus, all other things being equal, a drop in the growth rate of the economy may have very detrimental long-term consequences for the employment opportunities of low-skilled individuals. Although spending more on ALMPs such as public employment services may improve the employment rates of this group of disadvantaged workers, in the light of our results, it thus does not appear sufficient to fight the negative consequences of adverse economic conditions. However, it appears that an important union density and strict EPL for permanent contracts reduce the impact of economic fluctuations on the employment opportunities of low-educated male workers, respectively, in the short- and long run, thus confirming our hypotheses (Model 3).

When we now focus on our findings for women in Model 3 (Table 2), as with the models regarding male employment, among variables affecting the cost of labour for women, union density, temporary EPL and consumption taxes have also been retained due to their relevance. However, in the case of union density, the effect seems to be linear and is rather strong, as a 1 standard deviation increase in union density would reduce the employment rate of female workers by 5.67 percentage points in a long-run perspective. Moreover, the more encompassing the wage coordination is, the lower their employment opportunities in the short run. Hence, the stronger the wage setting institutions, the more acute the exclusion of low-educated women from the labour market.

On the side of policies improving the matching of skills, the findings for women are rather similar as the previous results for male low-skilled workers. The extent of job displacement is, however, even more salient as an increase in the share of low-skill female employment permanently reduces the employment opportunities of women by 5.83 percentage points. Furthermore, the proportion of loweducated female workers here has only a short-term impact but of high magnitude.

Finally, economic growth has a strong impact in the long run but a weaker effect in the short term than for men, thus confirming our hypothesis. And this is further supported by the observation that the short-term effect of growth in the case of men is due to the impact of the financial crisis, ${ }^{8}$ hence confirming that low-educated male workers are more likely to be affected by the economic conditions in the short run than women. In addition, highly coordinated wage-setting processes appear to enhance the effect of economic fluctuations on the employment opportunities of low-skilled women. In times of economic growth, low-educated women will thus enjoy higher employment prospects thanks to more encompassing wage bargaining institutions, whereas the lack of flexibility of the wage setting will further exclude them from the labour market during economic downturns.

\section{Sensitivity analysis}

As previously mentioned and discussed in Beck and Katz (2011), the apparent non-stationarity of our 
Table 2. The determinants of the employment rates of low-educated female workers.

\begin{tabular}{|c|c|c|c|c|c|}
\hline & & \multicolumn{4}{|l|}{ Women } \\
\hline & & Model I & Model 2 & Model 3 & Model 4 \\
\hline Low-educated female employment rate & Lag & $-0.06 * *$ & $-.07 * *$ & $-0.06 * *$ & $-0.05^{* *}$ \\
\hline Union density & $\begin{array}{l}\text { First difference } \\
\text { Lag }\end{array}$ & $\begin{array}{l}-4.56 \\
-0.27\end{array}$ & $\begin{array}{l}3.71 \\
-.50\end{array}$ & $\begin{array}{l}-5.37 * \\
-0.34 * *\end{array}$ & $\begin{array}{l}-5.31^{*} \\
-0.20\end{array}$ \\
\hline Union density squared & $\begin{array}{l}\text { First difference } \\
\text { Lag }\end{array}$ & & $\begin{array}{r}-7.35 \\
0.83\end{array}$ & & \\
\hline Coordination of wage bargaining & $\begin{array}{l}\text { First difference } \\
\text { Lag }\end{array}$ & $\begin{array}{r}-0.50 \\
0.01\end{array}$ & $\begin{array}{l}-.69 * \\
-.50\end{array}$ & $\begin{array}{l}-0.70^{* *} \\
-0.30\end{array}$ & $\begin{array}{l}-0.53^{*} \\
-0.08\end{array}$ \\
\hline Permanent EPL & $\begin{array}{l}\text { First difference } \\
\text { Lag }\end{array}$ & $\begin{array}{l}-0.70 \\
-14\end{array}$ & $\begin{array}{l}-.03 \\
0.59\end{array}$ & & \\
\hline Temporary EPL & $\begin{array}{l}\text { First difference } \\
\text { Lag }\end{array}$ & $\begin{array}{l}1.70 * \\
0.56 * *\end{array}$ & $\begin{array}{c}3.78^{*} \\
.85\end{array}$ & $\begin{array}{l}1.68^{*} \\
0.47 * * *\end{array}$ & $\begin{array}{l}1.69 * \\
0.34 *\end{array}$ \\
\hline Consumption tax revenues & $\begin{array}{l}\text { First difference } \\
\text { Lag }\end{array}$ & $\begin{array}{l}1.90^{*} \\
0.25\end{array}$ & $\begin{array}{l}1.65^{*} \\
0.03\end{array}$ & $\begin{array}{l}2.22 * * \\
0.28\end{array}$ & \\
\hline Social contributions & $\begin{array}{l}\text { First difference } \\
\text { Lag }\end{array}$ & $\begin{array}{l}0.68 \\
-.27^{*}\end{array}$ & $\begin{array}{r}1.22 \\
-0.18\end{array}$ & & \\
\hline Net replacement rate & $\begin{array}{l}\text { First difference } \\
\text { Lag }\end{array}$ & $\begin{array}{l}-.51 \\
0.01\end{array}$ & $\begin{array}{l}-0.78 \\
-0.01\end{array}$ & & \\
\hline Public employment services & $\begin{array}{l}\text { First difference } \\
\text { Lag }\end{array}$ & $\begin{array}{l}0.28 \\
0.37 * * *\end{array}$ & $\begin{array}{l}0.49 \\
.50 * * *\end{array}$ & $\begin{array}{l}0.46 \\
0.4 I^{* * * *}\end{array}$ & $\begin{array}{l}0.28 \\
0.29 * *\end{array}$ \\
\hline Training & $\begin{array}{l}\text { First difference } \\
\text { Lag }\end{array}$ & $\begin{array}{l}0.87^{*} \\
0.09\end{array}$ & $\begin{array}{l}0.88 * \\
0.19\end{array}$ & $\begin{array}{l}0.85^{*} \\
0.15\end{array}$ & $\begin{array}{l}0.8 I^{*} \\
0.28 *\end{array}$ \\
\hline Employment incentives & $\begin{array}{l}\text { First difference } \\
\text { Lag }\end{array}$ & $\begin{array}{l}0.10 \\
0\end{array}$ & $\begin{array}{r}0.14 \\
-0.22\end{array}$ & & \\
\hline Direct job creation & $\begin{array}{l}\text { First difference } \\
\text { Lag }\end{array}$ & $\begin{array}{l}-0.57 \\
-0.22\end{array}$ & $\begin{array}{l}-0.91 * \\
-0.39 * *\end{array}$ & $\begin{array}{l}-0.85^{* *} \\
-0.32^{* *}\end{array}$ & \\
\hline $\begin{array}{l}\text { Share of women in ISCO } 5 \text { and } 9 \text { jobs, } \\
\text { as a percentage of total employment }\end{array}$ & $\begin{array}{l}\text { First difference } \\
\text { Lag }\end{array}$ & $\begin{array}{l}0.29 \\
-0.34 * * *\end{array}$ & $\begin{array}{l}0.32 \\
-.48 * * *\end{array}$ & $\begin{array}{l}0.29 \\
-0.35 * *\end{array}$ & $\begin{array}{l}0.22 \\
-0.27 * *\end{array}$ \\
\hline $\begin{array}{l}\text { Proportion of low-educated female } \\
\text { workers }\end{array}$ & $\begin{array}{l}\text { First difference } \\
\text { Lag }\end{array}$ & $\begin{array}{l}7.08 * * * \\
0.11\end{array}$ & $\begin{array}{l}6.99 * * * \\
0.23\end{array}$ & $\begin{array}{l}6.96 * * * \\
0.23\end{array}$ & $\begin{array}{l}7.34 * * * \\
0.36 * *\end{array}$ \\
\hline Growth & $\begin{array}{l}\text { First difference } \\
\text { Lag }\end{array}$ & $\begin{array}{l}0.31 * \\
0.83 * * *\end{array}$ & $\begin{array}{l}0.53 \\
0.83\end{array}$ & $\begin{array}{l}0.32 \\
0.12\end{array}$ & $\begin{array}{l}0.30 * * \\
0.7 \mathrm{I} * * *\end{array}$ \\
\hline $\begin{array}{l}\text { Interaction permanent EPL } \times \text { temporary } \\
\text { EPL }\end{array}$ & $\begin{array}{l}\text { First difference } \\
\text { Lag }\end{array}$ & & $\begin{array}{l}-0.64 \\
-0.10\end{array}$ & & \\
\hline Interaction growth $\times$ wage coordination & $\begin{array}{l}\text { First difference } \\
\text { Lag }\end{array}$ & & $\begin{array}{l}-0.14 \\
1.28 * *\end{array}$ & $\begin{array}{l}-0.01 \\
0.76^{*}\end{array}$ & \\
\hline Interaction growth $\times$ union density & $\begin{array}{l}\text { First difference } \\
\text { Lag }\end{array}$ & & $\begin{array}{l}-0.18 \\
-0.82\end{array}$ & & \\
\hline Interaction growth $\times$ permanent EPL & $\begin{array}{l}\text { First difference } \\
\text { Lag }\end{array}$ & & $\begin{array}{r}-.04 \\
-0.69\end{array}$ & & \\
\hline Interaction growth $\times$ temporary EPL & $\begin{array}{l}\text { First difference } \\
\text { Lag }\end{array}$ & & $\begin{array}{l}0.08 \\
0.04\end{array}$ & & \\
\hline Constant & & $4.21 * *$ & $4.37 * *$ & 3.95 **** & $3.37^{* *}$ \\
\hline $\mathrm{N}$ & & 19 & 19 & 19 & 19 \\
\hline Average $T$ & & 10.63 & 10.63 & 11 & II \\
\hline $\mathrm{n}$ & & 202 & 202 & 209 & 209 \\
\hline $\mathrm{R}^{2}$ & & 0.62 & 0.65 & 0.62 & 0.59 \\
\hline
\end{tabular}

EPL: employment protection legislation; ISCO: International Standard Classification of Occupations.

Standardized coefficients.

$* p<0.05 ; * * p<0.01 ; * * * p<0.001$. 
dependent variable may just be the result of the lack of availability of data over a longer period of time. Therefore, to test for the robustness of our findings, we specify a new model that ignores this apparent problem of stationarity. In order to do so, we start from the more complex ADL model and test for a potential simplification of the dynamics into a serially correlated (SC) or lagged dependent variable (LDV) model, basing ourselves on the most consistent models obtained using the EC form. In both cases, the simplification is rejected at the $1 \%$ level, thus confirming the pertinence of the ADL model for our data. ${ }^{9}$ Using this new specification, we reestimate our previous analyses. Because the coefficient of the lag of the dependent variable is very close to 1 , it is the strongest predictor of the model and, with the other covariates, explains almost $95 \%$ of the variance, hence making us doubt about the validity of the ADL model and confirming the need to rely on the EC form. Furthermore, an augmented DickeyFuller unit root test confirms that, both in the case of men and women, we might be dealing with integrated series (Table 3 ).

Furthermore, for the most consistent models of Tables 1 and 2, in which only the significant independent variables were included, a Lagrange multiplier test was performed to check for the auto-correlation of the errors, while potential heterogeneity issues were investigated through a leave-one-out cross-validation test done with both countries and years. The former confirmed the robustness of the residuals, while the results of the latter are displayed in Table 4 in Appendix 1. In the case of women, our most consistent model has been reestimated while excluding Switzerland, which appears as an outlier. The results do not vary whether it is included or not, though.

Granger causality tests were also performed when we suspected covariates having a short-run effect to be also determined by our dependent variable. As indicated in Table 5, in most cases, the expected direction of causality is confirmed, except for the impact of consumption taxes and direct job creation on the employment rates of female low-educated workers. As a result, these variables were dropped from the previous analysis and a new model was estimated (Model 4 in Table 2). The main differences with the previous model pertain to the lack of significance of the interaction effect of the centralization of wage bargaining and growth, while the short- and long-term effects of, respectively, union density, spending on training ALMPs and the proportion of low-educated female workers are now significant.

Finally, we avoided the inclusion of fixed effects for several reasons. First, it is well known that it results in a bias induced by the correlation of the centred LDV and the centred error term, which becomes particularly acute when $\mathrm{T}$ is small (Beck and Katz, 2011). While the Kiviet and Anderson-Hsiao estimators have been devised to correct this bias occurring with panel data, it appears that they do not perform well when applied to time-series cross-section data (Beck and Katz, 2011; Judson and Owen, 1999). Finally, country fixed effects take up all the crosscountry variations and yield coefficients that only measure the within-effect of independent variables. Not only does it affect time-invariant predictors, but it also reduces the impact of time-varying variables to their within-effect, while ignoring the between-effect (Beck and Katz, 2001; Bell and Jones, 2014). Because we are also interested in the impact of institutional factors in a cross-sectional fashion at the theoretical level, we therefore prefer to abstain from including fixed effects in our models. ${ }^{10}$

\section{Discussion}

In increasingly tertiarized economies, with technology affecting skill requirements and increasing the risk of a polarization of labour demand, policy-makers face important challenges in the task of improving the labour market situation of low-educated workers. As we could previously observe, however, the employment issues of low-educated workers may not be easily resolved. The interpretation of our findings may even sound quite pessimistic, as economic conditions seem to be the most important factor in determining the employment opportunities of male low-skilled workers. With economic recession destroying jobs both immediately and in the long term through deep structural changes, and causing the unemployment of many low-skilled workers who are unable to reintegrate the labour market, there are reasons to be worried. What, then, should be done? 
Despite the fact that economic growth matters a great deal in the creation of jobs for the low skilled, labour market institutions may nonetheless further limit the detrimental consequences of economic downturns. In the case of men, a higher union density and stricter EPL for regular contracts appear to weaken the effect of economic fluctuations.

On the other hand, ALMPs affecting the supply, such as spending on public employment services, may meaningfully support the reintegration of unemployed low-educated workers into the labour market. However, among all the ALMPs included, namely, the aforementioned public employment services, training, job subsidization and direct job creation, only the first two positively affect employment rates for both male and female workers with low educational qualifications, while more spending on direct job creation hampers their employment opportunities. Distinguishing between the different types of ALMPs is thus clearly necessary in order to better understand how to improve the employment prospects of low-educated workers. This finding is also in accordance with the evaluation literature on the subject and confirms the usefulness of a better characterization of these policies (e.g. Bonoli, 2012). In the case of unemployed workers with low educational qualifications, it thus appears that ALMPs that put pressure on these workers, or assisting them in their job search, are the most effective (and maybe also the most efficient).

While economists such as Heckman (2007) insist on the need to focus on how labour market institutions shape employment opportunities through their impact on the cost of labour determining the creation of jobs, as evidenced here, this focus neglects a large piece of the puzzle. Furthermore, our findings tend to contradict this conventional wisdom. There are several reasons to this invalidation of the orthodox view. First, our focus is on the low-educated workers, a group that has been particularly affected by the recent structural changes of labour markets and whose employment prospects are supposed to depend strongly on the costs of labour. Second, we account for demand-side policies and the importance of the matching of skills in the labour market, which has been largely ignored by the orthodox view. Finally, we incorporate both the short- and long-run effects of our predictors in our empirical analysis, thus providing more reliable estimates that account for the complex time dynamics in the labour market, while correcting for well-known specification issues found in the literature supporting the conventional wisdom, in particular, reverse causality (Howell et al., 2007).

\section{Funding}

This research received no specific grant from any funding agency in the public, commercial or not-for-profit sectors.

\section{Notes}

1. A Matthew effect depicts the increase in the advantage/disadvantage of an already advantaged/disadvantaged group or individual over time, mostly following the introduction of a policy.

2. Due to the nature of the data, we are unfortunately unable to control for these factors at the individual or household level.

3. These data were retrieved from the Key Indicators of the Labour Market From the International Labour Organization, available at http://www.ilo.org/ empelm/what/WCMS_114240/lang-en/index.htm

4. Although there are reasons to doubt, employment rates can be non-stationary. See the discussion in Beck and Katz (2011).

5. Starting from the empty model, we obtained the same final model, confirming the robustness of our results. This procedure is particularly useful in that our $\mathrm{T}$ is relatively small and the asymptotics of the model are precisely in $\mathrm{T}$.

6. In order to interpret the effect of the lagged independent variable, it is necessary to divide the coefficient given in the table by the absolute value of the lag of the dependent variable to obtain the overall impact that will be spread over future periods.

7. Many thanks to Giuliano Bonoli for helping me with the interpretation of this result.

8. In order to do so, we dropped all observations from the years 2008 and 2009 and then compared the effect of growth between the models with and without these years.

9. For more precision on the nature of the tests, see Beck and Katz (2011).

10. In the case of the impact of the share of low-end service jobs in the economy on the employment rates of male low-educated workers, including country fixed effects resulted in a lack of significance as well as a change in the sign of the coefficient of the lagged 
variable. This is a perfect example of the importance of cross-country variation to capture the structural effect of our independent variables.

\section{References}

Abrassart, A. (2013) 'Cognitive Skills Matter: The Employment Disadvantage of Low-Educated Workers in Comparative Perspective', European Sociological Review 29(4): 707-19.

Autor, D.H., Levy, F. and Murnane, R.J. (2003) 'The Skill Content of Recent Technological Change: An Empirical Exploration', Quarterly Journal of Economics 118(4): 1279-333.

Avdagic, S. and Salardi, P. (2013) 'Tenuous Link: Labour Market Institutions and Unemployment in Advanced and New Market Economies', Socio-Economic Review 11(4): 739-69.

Baccaro, L. and Rei, D. (2007) 'Institutional Determinants of Unemployment in OECD Countries: Does the Deregulatory View Hold Water?', International Organization 61(3): 527-69.

Beck, N. and Katz, J.N. (2001) 'Throwing out the Baby with the Bath Water: A Comment on Green, Kim and Yoon', International Organization 55(2): 487-95.

Beck, N. and Katz, J.N. (2011) 'Modeling Dynamics in Time-Series-Cross-Section Political Economy Data', Annual Review of Political Science 14: 331-52.

Bell, A. and Jones, K. (2014) 'Explaining Fixed Effects: Random Effects Modeling of Time-Series CrossSectional and Panel Data', Political Science Research and Methods 1-21, available at http:// dx.doi.org/10.1017/psrm.2014.7.

Blanchard, O. and Landier, A. (2002) 'The Perverse Effects of Partial Labour Market Reform: FixedTerm Contracts in France', The Economic Journal 112: $214-44$.

Bonoli, G. (2007) 'Time Matters: Postindustrialiszation, New Social Risks, and Welfare State Adaptation in Advanced Industrial Democracies', Comparative Political Studies 40: 495-520.

Bonoli, G. (2010) 'The Political Economy of Active Labor-Market Policy', Politics \& Society 38(4): 435-57.

Bonoli, G. (2012) 'The Postindustrial Employment Problem and Active Labour Market Policy', Paper Prepared for Presentation at the 10th ESPAnet Annual Conference, Edinburgh, 6-8 September.

Bradley, D.H. and Stephens, J.D. (2007) 'Employment Performance in OECD countries: A Test of Neoliberal and Institutionalist Hypotheses', Comparative Political Studies 40(12): 1-25.
Cahuc, P. and Postel-Vinay, F. (2002) 'Temporary Jobs, Employment Protection and Labor Market Performance', Labour Economics 9: 63-91.

Clasen, J. and Clegg, D. (2003) 'Unemployment Protection and Labour Market Reform in France and Great Britain in the 1990s: Solidarity Versus Activation?', Journal of Social Policy 32: 361-81.

DiPrete, T.A. (2005) 'Labor Markets, Inequality, and Change: A European Perspective', Work and Occupations 32(2): 119-39.

Eichhorst, W. and Marx, P. (2012) 'Whatever Works: Dualisation and the Service Economy in Bismarckian Welfare States', in P. Emmenegger, S. Häusermann, B. Palier and M. Seeleib-Kaiser (eds) The Age of Dualization: The Changing Face of Inequality in Deindustrializing Societies, pp. 73-99. Oxford: Oxford University Press.

Emmenegger, P., Häusermann, S., Bruno, P. and SeeleibKaiser, M. (2012) 'How We Grow Unequal', in P. Emmenegger, S. Häusermann, B. Palier and M. Seeleib-Kaiser (eds) The Age of Dualization: The Changing Face of Inequality in Deindustrializing Societies, pp. 3-26. Oxford: Oxford University Press.

Esping-Andersen, G. (1999) Social Foundations of Postindustrial Economies. Oxford: Oxford University Press.

Esping-Andersen, G. (2000) 'Who is Harmed by Labour Market Regulations?', in G. Esping-Andersen and M. Regini (eds) Why Deregulate Labour Markets? pp. 66-98. Oxford: Oxford University Press.

Estevez-Abe, M., Iversen, T. and Soskice, D. (2001) 'Social Protection and the Formation of Skills: A Reinterpretation of the Welfare State', in P. Hall and D. Soskice (eds) Varieties of Capitalism, pp. 145-83. New York: Oxford University Press.

Gangl, M. (2004) 'Welfare States and the Scar Effects of Unemployment: A Comparative Analysis of the United States and West Germany', American Journal of Sociology 109(6): 1319-64.

Garrett, G. and Way, C. (1999) 'Public Sector, Unions, Corporatism, and Macroeconomic Performance', Comparative Political Studies 32(4): 411-34.

Gautier, P.A., van den Berg, G., van Ours, J. and Ridder, G. (2002) 'Worker Turnover at the Firm Level and Crowding out of Lower Educated Workers', European Economic Review 46: 523-38.

Gesthuizen, M., Solga, H. and Künster, R. (2011) 'Context Matters: Economic Marginalization of Low-Educated Workers in Cross-National Perspective', European Sociological Review 27(2): 264-80.

Goos, M. and Manning, A. (2007) 'Lousy and Lovely Jobs: The Rising Polarization of Work in Britain', 
The Review of Economics and Statistics 89(1): 118-33.

Heckman, J.J. (2007) 'Comments on Are Protective Labor Market Institutions at the Root of Unemployment? A Critical Review of the Evidence by David Howell, Dean Baker, Andrew Glyn, and John Schmitt', Capitalism and Society 2(1): 5 (4 pp.).

Hicks, A. and Kenworthy, L. (1998) 'Cooperation and Political Economic Performance in Affluent Democratic Capitalism', American Journal of Sociology 103(6): 1631-72.

Howell, D.R., Baker, D., Glyn, A. and Schmitt, J. (2007) 'Are Protective Labor Market Institutions at the Root of Unemployment? A Critical Review of the Evidence', Capitalism and Society 2(1): 1 (71 pp.).

Iversen, T. and Cusack, T.R. (2000) 'The Causes of Welfare State Expansion: Deindustrialization or Globalization?', World Politics 52(3): 313-49.

Iversen, T. and Wren, A. (1998) 'Equality, Employment and Budgetary Restraint: The Trilemma of the Service Economy', World Politics 50(4): 507-46.

Judson, K.A. and Owen, A.L. (1999) 'Estimating Dynamic Panel Data Models: A Guide for Macroeconomists', Economics Letters 65(1): 9-15.

Kahn, L.M. (2005) 'The Impact of Employment Protection Mandates on Demographic Temporary Employment Patterns: International Microeconomic Evidence', Discussion Paper 1548. Bonn: Institute for the Study of Labor.

Kenworthy, L. (2003) 'Do Affluent Countries Face an Incomes-Jobs Trade-Off?', Comparative Political Studies 36(10): 1180-209.

Kenworthy, L. (2008) Jobs with Equality. Oxford: Oxford University Press.

Lodovici, M.S. (2000) 'The Dynamics of Labour Market Reform in European Countries', in G. EspingAndersen and M. Regini (eds) Why Deregulate Labour Markets? pp. 30-65. Oxford: Oxford University Press.

Marx, I. (2001) 'Job Subsidies and Cuts in Employers' Social Security Contributions: The Verdict of Empirical Evaluation Studies', International Labour Review 140(1): 69-83.

Maurin, E. and Postel-Vinay, F. (2005) 'The European Job Security Gap', Work and Occupations 32(2): 229-52.
Organisation for Economic Co-operation and Development (OECD) (1994) The OECD Jobs Study. Paris: OECD.

Organisation for Economic Co-operation and Development (OECD) (2012) OECD Education at a Glance 2012. Paris: OECD.

Oesch, D. (2010) 'What Explains High Unemployment among Low-Skilled Workers? Evidence from 21 OECD Countries', European Journal of Industrial Relations 16(1): 39-55.

Oesch, D. and Menés, J.R. (2011) 'Upgrading or Polarization? Occupational Change in Britain, Germany, Spain and Switzerland, 1990-2008', Socio-Economic Review 9(3): 503-32.

Palier, B. and Thelen, K. (2010) 'Institutionalizing Dualism: Complementarities and Change in France and Germany', Politics \& Society 38(1): 119-48.

Plümper, T., Troeger, V.E. and Manow, P. (2005) 'Panel Data Analysis in Comparative Politics: Linking Method to Theory', European Journal of Political Research 44(2): 327-54.

Scharpf, F.W. (2000) 'Economic Changes, Vulnerabilities, and Institutional Capabilities', in F.W. Scharpf and V.A. Schmidt (eds) Welfare and Work in the Open Economy. Volume I: From Vulnerability to Competitiveness, pp. 21-124. Oxford: Oxford University Press.

Siebert, H. (1997) 'Labor Market Rigidities: At the Root of Unemployment in Europe', Journal of Economic Perspectives 11(3): 37-54.

Van Vliet, O. and Caminada, K. (2012) Unemployment Replacement Rates Dataset among 34 Welfare States 1971-2009: An Update, Extension and Modification of Scruggs 'Welfare State Entitlements Data Set'. NEUJOBS Special Report, no. 2, January. Leiden: Leiden University.

Visser, J. (2011) The ICTWSS Database: Database on Institutional Characteristics of Trade Unions, Wage Setting, State Intervention and Social Pacts in 34 Countries between 1960 and 2007. Amsterdam: Amsterdam Institute for Advanced Labour Studies (AIAS), University of Amsterdam.

Weber, A. and Mahringer, H. (2008) 'Choice and Success of Job Search Methods', Empirical Economics 35(1): 153-78. 


\section{Appendix I}

Table 3. Augmented Dickey-Fuller unit root tests.

\begin{tabular}{|c|c|c|c|c|}
\hline & \multicolumn{2}{|l|}{ Men } & \multicolumn{2}{|l|}{ Women } \\
\hline & Statistic & $\mathrm{P}$-value & Statistic & $\mathrm{p}$-value \\
\hline Inverse chi-squared & 34.95 & 0.88 & 39.49 & 0.74 \\
\hline Inverse normal & 0.77 & 0.78 & 2.13 & 0.98 \\
\hline Inverse logit & 0.77 & 0.78 & 2.23 & 0.99 \\
\hline Modified inverse chi-squared & -1.15 & 0.88 & -0.68 & 0.75 \\
\hline
\end{tabular}

All panels contain unit roots as the null hypothesis. A p-value above 0.05 indicates that we have more than $5 \%$ chance of being wrong in rejecting the null hypothesis. The series are thus integrated.

Table 4. Country and year leave-one-out cross-validation.

\begin{tabular}{|c|c|c|}
\hline & \multicolumn{2}{|c|}{ Root mean squared error } \\
\hline & Men & Women \\
\hline \multicolumn{3}{|l|}{ Country } \\
\hline Australia & 1.27 & 1.31 \\
\hline Austria & 1.27 & 1.32 \\
\hline Belgium & 1.29 & 1.33 \\
\hline Canada & 1.29 & 1.32 \\
\hline Denmark & 1.24 & 1.26 \\
\hline Finland & 1.29 & 1.30 \\
\hline France & 1.27 & 1.31 \\
\hline Germany & 1.29 & 1.32 \\
\hline Ireland & 1.26 & 1.32 \\
\hline Italy & 1.26 & 1.30 \\
\hline The Netherlands & 1.25 & 1.32 \\
\hline New Zealand & 1.29 & 1.32 \\
\hline Norway & 1.21 & 1.29 \\
\hline Portugal & 1.28 & 1.32 \\
\hline Spain & 1.24 & 1.31 \\
\hline Sweden & 1.30 & 1.31 \\
\hline Switzerland & 1.25 & 1.14 \\
\hline United Kingdom & 1.27 & 1.33 \\
\hline United States & 1.27 & 1.31 \\
\hline \multicolumn{3}{|l|}{ Year } \\
\hline 1997 & 1.27 & 1.30 \\
\hline 1998 & 1.29 & 1.32 \\
\hline 1999 & 1.28 & 1.24 \\
\hline 2000 & 1.25 & 1.30 \\
\hline 2001 & $\mid .31$ & 1.23 \\
\hline 2002 & 1.29 & 1.33 \\
\hline 2003 & 1.26 & 1.29 \\
\hline
\end{tabular}


Table 4. (Continued)

\begin{tabular}{lll}
\hline & Root mean squared error & \\
\cline { 2 - 3 } & Men & Women \\
\hline 2004 & 1.26 & 1.33 \\
2005 & 1.23 & 1.29 \\
2006 & 1.32 & 1.34 \\
2007 & 1.26 & 1.32 \\
2008 & 1.26 & 1.32 \\
2009 & 1.21 & 1.33 \\
2010 & & 1.29 \\
\hline
\end{tabular}

Table 5. Granger causality tests: Chi square and critical probability (in brackets).

\begin{tabular}{lcllll}
\hline & $\begin{array}{l}\text { Consumption } \\
\text { taxes }\end{array}$ & $\begin{array}{l}\text { Spending on } \\
\text { training ALMPs }\end{array}$ & $\begin{array}{l}\text { Temporary } \\
\text { EPL }\end{array}$ & $\begin{array}{l}\text { Economic } \\
\text { growth }\end{array}$ & $\begin{array}{l}\text { Direct job } \\
\text { creation }\end{array}$ \\
\hline $\begin{array}{l}\text { Male } \\
\text { employment rate }\end{array}$ & $0(0.9827)$ & $0.02(0.8797)$ & $0.67(0.4122)$ & $0.71(0.4009)$ & \\
$\begin{array}{l}\text { Female } \\
\text { employment rate }\end{array}$ & $9.79(0.0018)$ & $1.20(0.2732)$ & $0.12(0.7272)$ & & $4.14(0.0419)$ \\
\hline
\end{tabular}

ALMPs: active labour market policies; EPL: employment protection legislation.

We test for the significance of the effect of the lag of the first difference of the dependent variable on the independent variables listed above, while controlling for the lag of these variables. These tests were not performed separately in each country because of the relatively low number of years. This is also why only one lag of the first differenced variables was included. 